\title{
PENGARUH PUPUK ORGANIK DAN PUPUK HAYATI TERHADAP POPULASI DAN BIOMASSA CACING TANAH PADA PERTANAMAN TOMAT CHERRY (Lycopersicum esculentum. Mill) DI DESA SUKBANJAR KECAMATAN GEDONG TATAAN
}

\section{THE EFFECT OF ORGANIC FERTILIZER AND BIO FERTILIZER POPULATION AND BIOMASS OF SOIL IN TOMATO CHERRY (Lycopersicum esculentum. Mill) PLANTS IN SUKBANJAR VILLAGE, GEDONG TATAAN VILLAGE}

\author{
Nadya Nurlita ${ }^{1}$, Sri Yusnaini ${ }^{1}$, Kushendarto ${ }^{1}$, dan M.A Syamsul Arif ${ }^{2}$ \\ ${ }^{1}$ Jurusan Agroteknologi, Fakultas Pertanian, Universitas Lampung, Bandar Lampung, Indonesia \\ ${ }^{2}$ Jurusan Ilmu Tanah, Fakultas Pertanian, Universitas Lampung, Bandar Lampung, Indonesia \\ *Email: nadyanurlita1@gmail.com \\ * Corresponding Author, Diterima: 12 Apr. 2021, Direvisi: 29 Apr. 2021, Disetujui: 28 Mei. 2021
}

\begin{abstract}
Earthworms is one of the soil biota that plays an active role in indicators of soil fertility. Organic fertilizers and biological fertilizers are suppliers of nutrients needed by the soil for plants and organism activities in the soil. This study aims to determine the effect of organic fertilizer, biofertilizer, and the interaction between organic and biofertilizer on the population and biomass of earthworms in cherry tomatoes (Lycopersicum esculentum Mill). This study were arranged by factorially Randomized Complete Block Design (RCBD). The first factor was the type of organic fertilizer $(\mathrm{K})$ and the second factor was the concentration of biological fertilizer $(\mathrm{M})$, each treatment was repeated three times to obtain 36 experimental unit plots. The data obtained were further analyzed with a variance at the $5 \%$ level that was first tested for the varience homogeneity using the Bartlett Test and additivity was tested by the Tukey Test. The mean value of the data was tested by the LSD test at $5 \%$ level. To find out the correlation between the supporting variables and the main variables, a correlation test was performed. The results showed that the treatment of chicken manure $\left(\mathrm{K}_{1}\right)$ increased the population and biomass of earthworms at 45 DAP observations at depths of $0-15 \mathrm{~cm}$ and $15-30 \mathrm{~cm}$ and at 90 DAP observations at depth $0-15 \mathrm{~cm}$, while the application of biological fertilizer did not significant affect the population and biomass of earthworms at 45 DAP and 90 DAP interaction both depths of $0-15 \mathrm{~cm}$ and $15-30 \mathrm{~cm}$. The both of organic and biological fertilizers did not had interaction observations of 45 DAP and 90 DAP at a depth of $0-15 \mathrm{~cm}$ and $15-30 \mathrm{~cm}$. Based on the identification, it was found that all earthworms at each depth in cherry tomato plantations belong to the megascolicidae family.
\end{abstract}

Keywords: Biological fertilizer, cherry tomatoes, earthworms, organic fertilizer.

\begin{abstract}
ABSTRAK
Cacing tanah merupakan salah satu biota tanah yang sangat berperan aktif dalam indikator kesuburan tanah. Pupuk organik dan pupuk hayati merupakan pensuplai hara yang dibutuhkan bagi tanah untuk tanaman dan aktivitas organisme di dalam tanah. Penelitian ini bertujuan untuk mengetahui pengaruh pemberian pupuk organik, aplikasi pupuk hayati, dan interaksi antara kedua pupuk tersebut terhadap populasi dan biomassa cacing tanah pada pertanaman tomat cherry (Lycopersicum esculentum Mill). Penelitian ini menggunakan Rancangan Acak
\end{abstract}


Kelompok (RAK) yang disusun secara faktorial, faktor pertama jenis pupuk organik (K) dan faktor kedua konsentrasi pupuk hayati (M), setiap perlakuan diulang sebanyak tiga kali sehingga diperoleh 36 petak satuan percobaan. Data yang diperoleh dianalisis dengan sidik ragam pada taraf $5 \%$ yang terlebih dahulu diuji homogenitas ragamnya dengan menggunakan Uji Bartlett dan additivitasnya diuji dengan Uji Tukey. Rata-rata nilai tengah dari data diuji dengan Uji BNT pada taraf 5\%. Untuk mengetahui hubungan antara variabel pendukung dengan variabel utama dilakukan uji korelasi. Hasil penelitian menunjukan bahwa perlakuan pupuk kandang ayam $\left(\mathrm{K}_{1}\right)$ meningkatkan populasi dan biomassa cacing tanah pada pengamatan 45 HST di kedalaman 0-15 cm dan 15-30 cm dan pada pengamatan 90 HST di kedalaman 0-15 cm, sedangkan pemberian pupuk hayati tidak berpengaruh nyata terhadap populasi dan biomassa cacing tanah pada pengamatan 45 HST dan 90 HST di kedalaman 0-15 $\mathrm{cm}$ dan $15-30 \mathrm{~cm}$. Pemberian pupuk organik dan pupuk hayati tidak terjadi interaksi pada pengamatan $45 \mathrm{HST}$ dan 90 HST di kedalaman 0-15 cm dan 15-30 cm. Berdasarkan identifikasi didapatkan bahwa semua cacing tanah setiap kedalaman pada pertanaman tomat cherry didapatkan cacing tanah tergolong dalam famili megascolicidae.

Kata kunci : Cacing tanah, pupuk hayati, pupuk organik, tomat cherry.

\section{PENDAHULUAN}

Tomat (Solanum lycopersicum) merupakan salah satu komoditas hortikultura yang bernilai ekonomi tinggi dan sangat banyak digemari masyarakat. Buah tomat memiliki banyak manfaat dan mengandung vitamin yang sangat penting bagi tubuh manusia. Potensi pasar buah tomat juga dapat dilihat dari segi harga yang terjangkau oleh seluruh lapisan masyarakat sehingga membuka peluang yang lebih besar terhadap serapan pasar (Dalimartha, 2011).

Tomat cherry berbentuk bulat dengan diameter 1.5-3 cm. Bobot buah \pm 30 gr, memiliki kulit buah tipis. Kulit buah ada yang berwarna merah muda, merah, oranye atau kuning (Opena and Van der Vossen, 1994). Biji tomat dikelilingi oleh bahan gel yang memenuhi rongga buah. Biji tomat berbentuk pipih dan berwarna krem muda. Biji tomat umumnya memiliki panjang 2-3 mm (Rubazky dan Yamaguchi, 1999). Tomat ini merupakan tanaman perdu semusim, berbatang lemah dan basah. Daunnya berbentuk segitiga. Bunganya berwarna kuning. Buahnya hijau waktu muda dan kuning atau merah waktu tua. Berbiji banyak, berbentuk bulat pipih, putih atau krem.

Berdasarkan data Badan Pusat Statistik (BPS, 2016) bahwa produksi buah tomat di Indonesia pada tahun 2014 adalah 915,987 ton, pada tahun 2015 terjadi penurunan menjadi 887,792 ton. Menurunnya produksi tomat dikarenakan kesuburan tanah yang rendah. Untuk meningkatkan kesuburan tanah perlu dilakukannya pemupukan.

Pemupukan merupakan salah satu kegiatan penting dalam budidaya tanaman tomat untuk menghasilkan pertumbuhan yang maksimal, karena pemupukan merupakan salah satu cara untuk menambah ketersediaan unsur hara didalam tanah, sehingga mampu menciptakan pertumbuhan tanaman yang baik dan memberikan produksi yang tinggi (Redaksi Agromedia, 2007). Salah satu untuk meningkat-kan ketersedian unsur hara didalam tanah dan memperbaiki sifat fisik tanah yaitu penambahan pupuk organik.

Pupuk organik adalah pupuk yang berasal dari sisa makhluk hidup baik hewan maupun tanaman pupuk 
organik yang diberikan pada penelitian ini adalah pupuk kandang ayam dan kompos jerami. Pupuk kandang ayam dan kompos jerami banyak terdapat di masyarakat dan belum maksimal digunakan. Pupuk kandang ayam dan kompos jerami dapat memperbaiki sifat fisik, kimia dan biologi tanah (Santoso, dkk, 2004 dan Pangaribuan dan Pujisiswanto, 2008)

Selain pupuk organik, pupuk hayati juga membantu dekomposisi bahan organik karena pupuk hayati mengandung berbagai jenis mikroba yang bermanfaat untuk meningkatkan kesuburan tanah secara biologi, pupuk hayati bisa berupa padatan atau cairan. Beberapa jenis mikroba yang terkandung dalam pupuk hayati adalah Azospirilium sp. untuk penambat nitrogen, Pseudomonas sp. untuk pelarut fosfat, Lactobacillus sp. , mikroba selulotik dan lainnya (Prayoga,2016).

Pupuk organik dan pupuk hayati yang ditambahkan ke dalam tanah, selain bermanfaat memperbaiki kesuburan tanah, juga dapat meningkatkan aktivitas mikroorganisme di dalam tanah, salah satunya adalah cacing tanah. Aktivitas cacing tanah dapat membuat lubang-lubang saluran di dalam tanah, menyebabkan air dapat dengan mudah menembus ke dalam tanah, sehingga cacing tanah ikut berperan dalam meningkatkan permeabilitas tanah (Marzuki dkk., 2011) diharapkan dengan meningkatnya populasi cacing tanah maka kesuburan tanah akan meningkat pada pertanaman tomat cherry.

Penelitian ini bertujuan untuk mempelajari perbedaan pemberian pupuk organik yang berbeda dalam meningkatkan populasi dan biomassa cacing tanah, mempelajari pengaruh aplikasi pupuk hayati dalam meningkatkan populasi cacing tanah dan biomassa cacing tanah pada tanaman tomat cherry dan mempelajari interaksi pemberian pupuk organik dan aplikasi pupuk hayati terhadap populasi cacing tanah dan biomassa cacing tanah pada tanaman tomat cherry.

\section{BAHAN DAN METODE}

Penelitian ini dilaksanakan di Desa Sukabanjar Kecamatan Gedong Tataan Kabupaten Pesawaran. Penelitian ini dilakukan pada bulan September 2018 - Desember 2018. Analisis cacing tanah dan sampel tanah dilakukan di Laboratorium Ilmu Tanah, Fakultas Pertanian, Universitas Lampung.

Penelitian ini dilakukan menggunakan Rancangan Acak Kelompok (RAK) yang disusun secara faktorial. Faktor pertama yaitu pupuk organik berupa pupuk kandang kotoran ayam $\left(\mathrm{K}_{1}\right)$ dan pupuk jerami $\left(\mathrm{K}_{2}\right)$. Faktor kedua menggunakan Pupuk Hayati (Bio Max Grow) dengan konsentrasi 10 m/1 ( $\left.\mathrm{M}_{1}\right), 20$ $\mathrm{ml} / \mathrm{l}\left(\mathrm{M}_{2}\right)$, dan $30 \mathrm{ml} / \mathrm{l}\left(\mathrm{M}_{3}\right)$.

Berdasarkan kedua faktor perlakuan pupuk hayati (Bio Max Grow) dan bahan organik diperoleh 12 kombinasi perlakuan sebagai berikut:

$\mathrm{K}_{0} \mathrm{M}_{0}=$ Tanpa bahan organik + Tanpa pupuk hayati (Bio Max Grow)

$\mathrm{K}_{0} \mathrm{M}_{1}=$ Tanpa bahan organik + Pupuk hayati (Bio Max Grow) $10 \mathrm{ml} / 1$

$\mathrm{K}_{0} \mathrm{M}_{2}=$ Tanpa bahan organik + Pupuk hayati (Bio Max Grow) $20 \mathrm{ml} / 1$

$\mathrm{K}_{0} \mathrm{M}_{3}=$ Tanpa bahan organik + Pupuk hayati (Bio Max Grow) $30 \mathrm{ml} / 1$

$\mathrm{K}_{1} \mathrm{M}_{0}=$ Pupuk organik (Pupuk kandang kotoran ayam)

+ Tanpa pupuk hayati (Bio Max Grow) 
$\mathrm{K}_{1} \mathrm{M}_{1}=$ Pupuk organik (Pupuk kandang kotoran ayam)

+ Pupuk hayati (Bio Max Grow) 10 ml/1

$\mathrm{K}_{1} \mathrm{M}_{2}=$ Pupuk organik (Pupuk kandang kotoran ayam)

+ Pupuk hayati (Bio Max Grow) 20 ml/1

$\mathrm{K}_{1} \mathrm{M}_{3}=$ Pupuk organik (Pupuk kandang kotoran ayam)

+ Pupuk hayati (Bio Max Grow) $30 \mathrm{ml} / 1$

$\mathrm{K}_{2} \mathrm{M}_{0}=$ Pupuk organik (pupuk jerami) + Tanpa pupuk

hayati (Bio Max Grow)

$\mathrm{K}_{2} \mathrm{M}_{1}=$ Pupuk organik (pupuk jerami) + Pupuk hayati

(Bio Max Grow) $10 \mathrm{ml} / 1$

$\mathrm{K}_{2} \mathrm{M}_{2}=$ Pupuk organik (pupuk jerami) + Pupuk hayati

(Bio Max Grow) 20 ml/1

$\mathrm{K}_{2} \mathrm{M}_{3}=$ Pupuk organik (pupuk jerami) + Pupuk hayati

(Bio Max Grow) $30 \mathrm{ml} / 1$

Setiap perlakuan diulang tiga kali serta diacak dalam kelompok, sehingga diperoleh jumlah petakan sebanyak 36 satuan percobaan dengan masing masing petakan seluas $2 \times 1 \mathrm{~m}^{-2}$. Pada percobaan tomat cherry di desa Sukabanjar, Kecamatan Gedong Tataan.

\section{Populasi dan biomassa cacing tanah}

Jumlah populasi cacing tanah (ekor $\mathrm{m}^{-2}$ ). Pengambilan cacing tanah diawali dengan membuat kuadran $25 \mathrm{~cm}$ x $25 \mathrm{~cm}$ dengan tali plastik kemudian digali dengan kedalaman lapisan tanah 0-15 cm dan $15-30 \mathrm{~cm}$. Lubang yang digali, diamati populasi cacing tanahnya setiap lapisan dengan menggunakan metode perhitungan tangan (handsorting). Populasi cacing tanah dihitung dengan rumus :

\footnotetext{
Populasi cacing tanah $=$ cacing besar + cacing kecil luas petak sampel $\left(\mathrm{m}^{2}\right)$
}
Biomassa cacing tanah $=$ cacing besar + cacing kecil luas petak sampel $\left(\mathrm{m}^{2}\right)$

\section{Analisis Data}

Data yang diperoleh diuji homogenitas ragamnya dengan menggunakan Uji Bartlett, sedangkan Uji Additivitas data akan diuji dengan Uji Tukey. Jika data dinyatakan homogen, data dianalisis dengan sidik ragam dan dilanjutkan dengan uji BNT pada taraf 5\%.Uji korelasi akan dilakukan pada variabel pendukung dengan populasi dan biomassa cacing tanah.

\section{HASIL DAN PEMBAHASAN}

\section{Populasi dan Biomassa Cacing Tanah}

Rekapitulasi hasil analisis ragam pengaruh pemberian pupuk organik dan pupuk hayati terhadap variabel pengamatan populasi dan biomassa cacng tanah (Tabel 1), perlakuan pupuk organik berpengaruh nyata terhadap semua variabel pengamatan, kecuali variabel pengamatan populasi cacing tanah di kedalaman 15-30 cm (90 HST) dan biomassa cacing tanah di kedalaman 15-30 cm (90 HST). Perlakuan pupuk hayati dan interaksi kedua perlakuan tidak berpengaruh nyata terhadap semua variabel pengamatan terhadap populasi cacing tanah maupun biomassa cacing tanah.

Hasil uji lanjut BNT 5\% (Tabel 2), di kedalaman 0-15 cm dan 15- $30 \mathrm{~cm}$ pada pengamatan 45 HST dan kedalaman 0-15 cmpadapengamatn90HST menunjukkan bahwa pupuk kandang ayam $\left(\mathrm{K}_{1}\right)$ menghasilkan populasi cacing tanah lebih tinggi dan berbeda nyata dibandingkan dengan pupuk jerami $\left(\mathrm{K}_{2}\right)$ dan tanpa pupuk organik $\left(\mathrm{K}_{0}\right)$, tetapi pupuk pupuk jerami $\left(\mathrm{K}_{2}\right)$ tidak berbeda nyata dengan tanpa pupuk organik $\left(\mathrm{K}_{0}\right)$. 
Tabel 1. Rekapitulasi hasil analisis ragam pengaruh pemberian pupuk organik dan aplikasi pupuk hayati terhadap populasi dan biomassa cacing tanah.

\begin{tabular}{|c|c|c|c|c|c|c|c|c|}
\hline \multirow{4}{*}{ Perlakuan } & \multicolumn{8}{|c|}{ Variabel Pengamatan Cacing Tanah } \\
\hline & \multicolumn{4}{|c|}{$45 \mathrm{HST}$} & \multicolumn{4}{|c|}{90 HST } \\
\hline & \multicolumn{2}{|c|}{$\begin{array}{l}\text { Populasi } \\
\left(\text { ekor }^{-2}\right)\end{array}$} & \multicolumn{2}{|c|}{$\begin{array}{c}\text { Biomassa } \\
\left(\mathrm{g} / \mathrm{m}^{-2}\right)\end{array}$} & \multicolumn{2}{|c|}{$\begin{array}{c}\text { Populasi } \\
\left({\left.\text { ekor } \mathrm{m}^{-2}\right)}\right.\end{array}$} & \multicolumn{2}{|c|}{$\begin{array}{c}\text { Biomassa } \\
\left(\mathrm{g} / \mathrm{m}^{-2}\right)\end{array}$} \\
\hline & $0-15 \mathrm{~cm}$ & $15-30 \mathrm{~cm}$ & $0-15 \mathrm{~cm}$ & $15-30 \mathrm{~cm}$ & $0-15 \mathrm{~cm}$ & $15-30 \mathrm{~cm}$ & $0-15 \mathrm{~cm}$ & $15-30 \mathrm{~cm}$ \\
\hline SK & \multicolumn{8}{|c|}{ F hitung dan signifikansi } \\
\hline $\mathrm{K}$ & $6,64^{*}$ & $3,90^{*}$ & $4,91 *$ & $5,02 *$ & $18,8^{*}$ & $3,35^{\text {tn }}$ & $18,8^{*}$ & $3,35^{\text {tn }}$ \\
\hline $\mathrm{M}$ & $0,68^{\mathrm{tn}}$ & $0,06^{\mathrm{tn}}$ & $0,33^{\mathrm{tn}}$ & $0,18^{\mathrm{tn}}$ & $1,95^{\mathrm{tn}}$ & $0,06^{\mathrm{tn}}$ & $1,95^{\text {tn }}$ & $0,06^{\mathrm{tn}}$ \\
\hline KXM & $0,47^{\text {tn }}$ & $0,97^{\text {tn }}$ & $0,52^{\text {tn }}$ & $0,80^{\text {tn }}$ & $1,11^{\mathrm{tn}}$ & $0,16 \mathrm{tn}$ & $1,11^{\mathrm{tn}}$ & $0,16^{\mathrm{tn}}$ \\
\hline
\end{tabular}

Keterangan : Tanda $*=$ berbeda nyata pada taraf $5 \%$; Tanda $\mathrm{tn}=$ tidak berbeda nyata pada taraf $5 \% ; \mathrm{K}=$ Pupuk orgnik; $\mathrm{M}=$ Pupuk hayati; $\mathrm{KXM}=$ Interaksi antara pupuk organik dan pupuk hayati.

Tabel 2. Hasil uji lanjut BNT 5\% pengaruh pemberian pupuk organik terhadap populasi cacing tanah di kedalaman 0-15 cm dan 15-30 cm pada pengamatan 45 HST dan 90 HST.

\begin{tabular}{lrcc}
\hline \multirow{2}{*}{ Perlakuan Pupuk Organik } & \multicolumn{3}{c}{ Populasi Cacing Tanah (ekor m ${ }^{-2}$ ) } \\
\cline { 2 - 4 } & $0-15 \mathrm{~cm}$ & $45 \mathrm{HST}$ & $90 \mathrm{HST}$ \\
\cline { 2 - 4 } & $100 \mathrm{~b}$ & $15-30 \mathrm{~cm}$ & $0-15 \mathrm{~cm}$ \\
\hline $\mathrm{K}_{0}$ (Tanpa Pupuk Organik) & $208 \mathrm{a}$ & $34 \mathrm{~b}$ & $82 \mathrm{~b}$ \\
$\mathrm{~K}_{1}$ (Pupuk Kandang Ayam) & $146 \mathrm{~b}$ & $56 \mathrm{a}$ & $194 \mathrm{a}$ \\
$\mathrm{K}_{2}$ (Pupuk Jerami) & 61 & $36 \mathrm{~b}$ & $120 \mathrm{~b}$ \\
\hline BNT 5\% & 17 & 38 \\
\hline
\end{tabular}

Keterangan : Nilai tengah yang diikuti oleh huruf yang sama tidak berbeda berdasarkan Uji Nyata Terkecil (BNT) pada taraf $5 \%$.

Tabel 3. Hasil uji lanjut BNT 5\% pengaruh pemberian pupuk organik terhadap biomassa cacing tanah di kedalaman 0-15 cm dan 15-30 cm pada pengamatan 45 HST dan 90 HST.

\begin{tabular}{lrrr}
\hline \multirow{2}{*}{ Perlakuan Pupuk Organik } & \multicolumn{3}{c}{ Biomassa Cacing Tanah $\left(\mathrm{g} / \mathrm{m}^{-2}\right)$} \\
\cline { 2 - 4 } & $0-15 \mathrm{~cm}$ & $15-30 \mathrm{~cm}$ & $90 \mathrm{HST}$ \\
\cline { 2 - 4 } & $2,69 \mathrm{~b}$ & $0,74 \mathrm{~b}$ & $15 \mathrm{~cm}$ \\
\hline $\mathrm{K}_{0}$ (Tanpa Pupuk Organik) & $4,99 \mathrm{a}$ & $1,34 \mathrm{a}$ & $4,67 \mathrm{~b}$ \\
$\mathrm{~K}_{1}$ (Pupuk Kandang Ayam) & $3,52 \mathrm{ab}$ & $0,86 \mathrm{~b}$ & $2,88 \mathrm{~b}$ \\
$\mathrm{~K}_{2}$ (Pupuk Jerami) & 1,54 & 0,42 & 0,92 \\
\hline BNT 5\% & \multicolumn{3}{c}{45} \\
\hline
\end{tabular}

Keterangan : Nilai tengah yang diikuti oleh huruf yang sama tidak berbeda berdasarkan Uji Nyata Terkecil (BNT) pada taraf $5 \%$.

Hasil uji lanjut BNT 5\% (Tabel 3), di kedalaman 0-15 cm pada pengamatan 45 HST menunjukkan bahwa pupuk kandang ayam $\left(\mathrm{K}_{1}\right)$ menghasilkan biomassa cacing tanah lebih tinggi dan tidak berbeda nyata dibandingkan dengan pupuk jerami $\left(\mathrm{K}_{2}\right)$, tetapi pupuk kandang ayam $\left(\mathrm{K}_{1}\right)$ berbeda nyata dengan tanpa pupuk organik $\left(\mathrm{K}_{0}\right)$. Sedangkan di kedalaman
15-30 cm pada pengamatan 45 HST dan 90 HST menunjukkan bahwa pupuk kandang ayam $\left(\mathrm{K}_{1}\right)$ menghasilkan biomassa cacing tanah lebih tinggi dan berbeda nyata dibandingkan dengan pupuk jerami $\left(\mathrm{K}_{2}\right)$ dan tanpa pupuk organik $\left(\mathrm{K}_{0}\right)$, tetapi pupuk jerami $\left(\mathrm{K}_{1}\right)$ tidak berbeda nyata dengan tanpa pupuk $\operatorname{organik}\left(\mathrm{K}_{0}\right)$. 


\section{Perubahan Sifat-Sifat Tanah Selama Pertanaman}

Tomat Cherry (Lycopersicum esculentum Mill)

Hasil analisis ragam (Tabel 4), pemberian pupuk organik dan aplikasi pupuk hayati maupun interaksi antara keduanya pada pengamatan 45 HST dan 90 HST tidak memberikan pengaruh yang nyata terhadap kadar air tanah dan suhu tanah.

Perubahan C-organik Tanah (\%) dan pH Tanah Selama Pertanaman Tomat Cherry (Lycopersi cum esculentum Mill)

Pada gambar 1, Menunjukkan bahwa analais C-organik sebelum perlakuan sebesar 0,95\% (sangat rendah) mengalami peningkatan pada perlakuan $\mathrm{K}_{1} \mathrm{M}_{0}$ menjadi $1,40 \%$ (rendah) pada fase 45 HST serta terjadi peningkatan juga pada pengamatan 90 HST perlakuan $\mathrm{K}_{2} \mathrm{M}_{0}$ menjadi $1.40 \%$ (rendah).

Gambar 2 menunjukkan bahwa analisis $\mathrm{pH}$ tanah sebelum perlakuan sebesar 6,09 mengalami peningkatan $\mathrm{pH}$ tanah pada perlakuan $\mathrm{K}_{1} \mathrm{M}_{0}$ menjadi 6,8 pada pengamatan 45 HST serta terjadi peningkatan $\mathrm{pH}$ tanah juga pada pengamatan 90 HST perlakuan $\mathrm{K}_{2} \mathrm{M}_{2}$ menjadi 6,18.

\section{Korelasi Antara C-organik Tanah, Kadar Air tanah, Suhu tanah, dan pH Tanah dengan Populasi dan Biomassa Cacing Tanah}

Hasil Uji korelasi (Tabel 5), C-organik tanah, kadar air tanah, dan suhu tanah dengan populasi cacing tanah tidak menunjukkan korelasi yang nyata, tetapi

Tabel 4. Ringkasan analisis ragam pengaruh pemberian pupuk organik dan aplikasi pupuk hayati terhadap kadar air tanah $(\%)$ dan suhu tanah $\left({ }^{\circ} \mathrm{C}\right)$ pada pengamatan 45 HST dan $90 \mathrm{HST}$.

\begin{tabular}{|c|c|c|c|c|c|c|}
\hline \multirow{3}{*}{ Perlakuan } & \multicolumn{4}{|c|}{ Kadar Air Tanah (\%) } & \multicolumn{2}{|c|}{ Suhu Tanah $\left({ }^{\circ} \mathrm{C}\right)$} \\
\hline & \multicolumn{2}{|c|}{$45 \mathrm{HST}$} & \multicolumn{2}{|c|}{$90 \mathrm{HST}$} & \multirow{2}{*}{45 HST } & \multirow{2}{*}{$90 \mathrm{HST}$} \\
\hline & $0-15 \mathrm{~cm}$ & $15-30 \mathrm{~cm}$ & $0-15 \mathrm{~cm}$ & $15-30 \mathrm{~cm}$ & & \\
\hline SK & \multicolumn{6}{|c|}{ F hitung dan signifikansi } \\
\hline $\mathrm{K}$ & $0,69^{\mathrm{tn}}$ & $1,91^{\text {tn }}$ & $0,53^{\text {tn }}$ & $0,03^{\mathrm{tn}}$ & $1,80^{\operatorname{tn}}$ & $0,25^{\mathrm{tn}}$ \\
\hline M & $1,12^{\text {tn }}$ & $0,22^{\text {tn }}$ & $0,46^{\text {tn }}$ & $2,83^{\text {tn }}$ & $0,13^{\text {tn }}$ & $0,98^{\text {tn }}$ \\
\hline $\mathrm{KxM}$ & $1,63^{\mathrm{tn}}$ & $1,40^{\text {tn }}$ & $0,50^{\text {tn }}$ & $1,55^{\text {tn }}$ & $0,70^{\text {tn }}$ & $0,53^{\text {tn }}$ \\
\hline
\end{tabular}

Keterangan : $\mathrm{SK}=$ Sumber Keragaman; tn $=$ tidak berbeda nyata pada taraf $5 \%$; Tanda $*$ = berbeda nyata pada taraf $5 \%$; $\mathrm{K}=$ Pupuk organik; $\mathrm{M}=$ Pupuk hayati; $\mathrm{KxM}=$ Interaksi antara pupuk organik dan pupuk hayati.

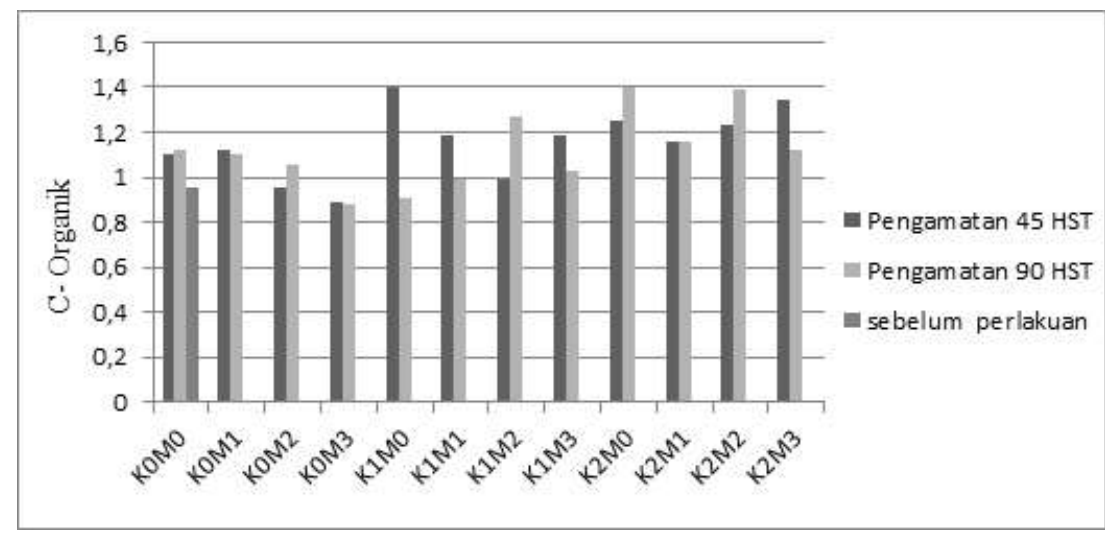

Gambar 1. Perubahan C-Organik tanah (\%) selama pertanaman tomat cherry

Keterangan : $\mathrm{K}_{0}=$ Tanpa pupuk organik, $\mathrm{K}_{1}=$ Pupuk kandang ayam, $\mathrm{K}_{2}=$ pupuk jerami, $\mathrm{M}_{0}=$ Tanpa pupuk hayati, $\mathrm{M}_{1}=\mathrm{Konsentrasi}$ pupuk hayati $10 \mathrm{ml} / 1, \mathrm{M}_{2}=$ Konsentrasi pupuk hayati $20 \mathrm{ml} / 1, \mathrm{M}_{3}=$ Konsentrasi pupuk hayati $30 \mathrm{ml} / 1$. 


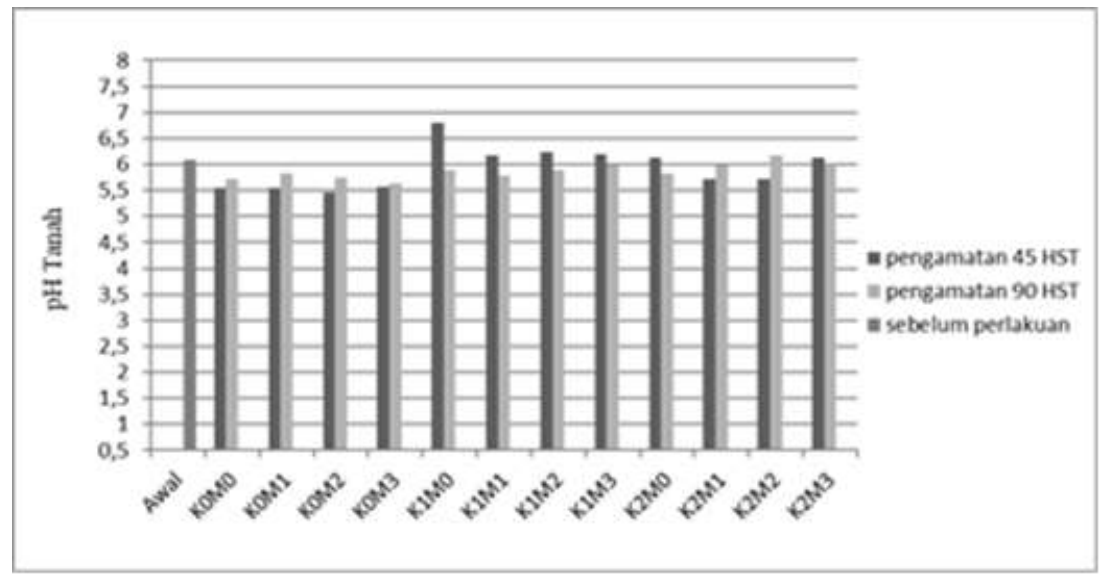

Gambar 2. Perubahan $\mathrm{pH}$ tanah selama pertanaman tomat cherry

Keterangan : $\mathrm{K}_{0}=$ Tanpa pupuk organik, $\mathrm{K}_{1}=$ Pupuk kandang ayam, $\mathrm{K}_{2}=$ pupuk jerami, $\mathrm{M}_{0}=$ Tanpa pupuk hayati, $\mathrm{M}_{1}=\mathrm{Konsentrasi}$ pupuk hayati $10 \mathrm{ml} / 1, \mathrm{M}_{2}=$ Konsentrasi pupuk hayati $20 \mathrm{ml} / 1, \mathrm{M}_{3}=$ Konsentrasi pupuk hayati $30 \mathrm{ml} / 1$.

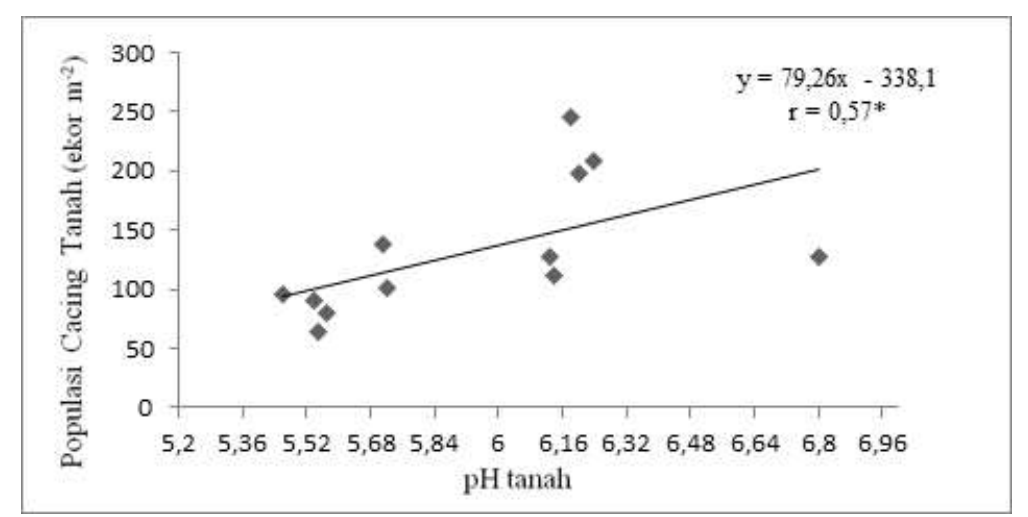

Gambar 3. Korelasi antara $\mathrm{pH}$ tanah dengan populasi cacing tanah pada pengamatan 45 HST.

Tabel 5. Uji Korelasi antara C-organik tanah, kadar ir tanah, suhu tanah, dan $\mathrm{pH}$ tanah dengan populasi cacing tanah.

\begin{tabular}{lcc}
\hline \multirow{2}{*}{ Pengamatan } & \multicolumn{2}{c}{ Koefisien Korelasi (r) } \\
\cline { 2 - 3 } & \multicolumn{2}{c}{ Populasi Cacing Tanah (ekor m-2 $)$} \\
\cline { 2 - 3 } & $45 \mathrm{HST}^{\mathrm{t}}$ & $00 \mathrm{HST}$ \\
\hline C-Organik (\%) & $0,44^{\text {tn }}$ & $0,16^{\text {n }}$ \\
Kadar Air Tanah (\%) & & $0,08^{\text {tn }}$ \\
-lapisan 1 $(0-15 \mathrm{~cm})$ & $0,12^{\text {tn }}$ & $0,04^{\text {tn }}$ \\
-lapisan 2 $(15-30 \mathrm{~cm})$ & $0,08^{\text {tn }}$ & $0,1^{\text {tn }}$ \\
Suhu Tanah $\left({ }^{\circ} \mathrm{C}\right)$ & $0,18^{\text {tn }}$ & $0,16^{\text {tn }}$ \\
pH Tanah & $0,57^{*}$ & \\
\hline
\end{tabular}

Keterangan : tn $=$ korelasi tidak nyata; $*=$ korelasi nyata, $\mathrm{n}=12$.

$\mathrm{pH}$ tanah menunjukkan korelasi nyata dengan populasi cacing tanah pada pengamatan 45 HST (Gambar 3). Sedangkan pada pengamatan 90 HST C-organik tanah, kadar air tanah, suhu tanah dan $\mathrm{pH}$ tanah menunjukkan tidak berkorelasi nyata dengan populasi cacing tanah.

Hasil Uji korelasi (Tabel 6), C-organik tanah, kadar air tanah, dan suhu tanah dengan biomassa cacing 
Tabel 6. Uji Korelasi antara C-organik tanah, kadar air tanah, suhu tanah, dan $\mathrm{pH}$ tanah dengan biomassa cacing tanah.

\begin{tabular}{lcc}
\hline \multirow{2}{*}{ Pengamatan } & \multicolumn{2}{c}{ Koefisien Korelasi (r) } \\
\cline { 2 - 3 } & \multicolumn{2}{c}{ Biomassa Cacing Tanah $\left(\mathrm{g} / \mathrm{m}^{-2}\right)$} \\
\cline { 2 - 3 } & $45 \mathrm{HST}$ & $90 \mathrm{HST}$ \\
\hline C-Organik (\%) & $0,45^{\text {tn }}, 03^{\text {tn }}$ \\
Kadar Air Tanah (\%) & & \\
-lapisan 1 $(0-15 \mathrm{~cm})$ & $0,13^{\text {tn }}$ & $0,07^{\text {tn }}$ \\
-lapisan 2 $(15-30 \mathrm{~cm})$ & $0,08^{\text {tn }}$ & $0,04^{\text {tn }}$ \\
Suhu Tanah $\left({ }^{\circ} \mathrm{C}\right)$ & $0,18^{\text {th }}$ & $0,1^{\text {tn }}$ \\
pH Tanah & $0,60^{*}$ & $0,16^{\text {tn }}$ \\
\hline
\end{tabular}

Keterangan : $\operatorname{tn}=$ korelasi tidak nyata; $*=$ korelasi nyata, $\mathrm{n}=12$.

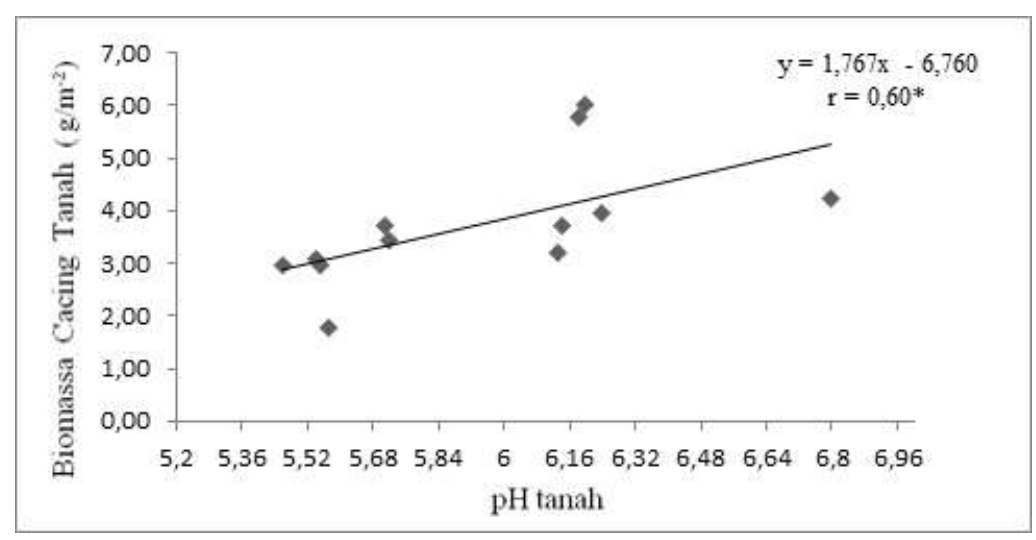

Gambar 4. Korelasi antara pH tanah dengan biomassa cacing tanah pada pengamatan 45 HST.

tanah tidak menunjukkan korelasi yang nyata, tetapi pH tanah menunjukkan korelasi nyata dengan populasi cacing tanah pada pengamatan 45 HST (Gambar 4). Sedangkan pada pengamatan 90 HST C-organik tanah, kadar air tanah, suhu tanah dan $\mathrm{pH}$ tanah menunjukkan tidak berkorelasi nyata dengan biomassa cacing tanah.

Pada Gambar 5. Menunjukkan bahwa pH tanah berkorelasi positif dengan populasi cacing tanah pada pengamatan 45 HST, artinya semakin tinggipH tanah yang berkisar 5,6-6,8 maka populasi cacing tanah semakin tinggi, sehingga kurva korelasi terlihat bahwa setiap peningkatan $\mathrm{pH}$ tanah sebesar 1 akan meningkatkan nilai populasi cacing tanah sebesar 79,2 ekor m$^{-2}$.
Gambar 6 menunjukkan bahwa $\mathrm{pH}$ tanah berkorelasi positif dengan biomassa cacing tanah pada pengamatan $45 \mathrm{HST}$, artinya semakin tinggi $\mathrm{pH}$ yang berkisar 5,6-6,8 maka populasi cacing tanah semakin tinggi, sehingga kurva korelasi terlihat bahwa setiap peningkatan $\mathrm{pH}$ tanah sebesar 1 akan meningkatkan nilai biomassa cacing tanah sebesar 1,76 gram $\mathrm{m}^{-2}$.

\section{Identifikasi Cacing Tanah}

Cacing tanah yang ditemukan pada penelitian termasuk ke dalam famili Megascolidae yang dicirikan letak klitelum berada di segmen ke - 24 (Gambar 7), Prostomium (Alat mulut) berpola Epilobus (Gambar 8) berbentuk bulatan kecil., dan Setae (Bulu halus) berpola Perisetin (Gambar 9) memiliki ciri setae 


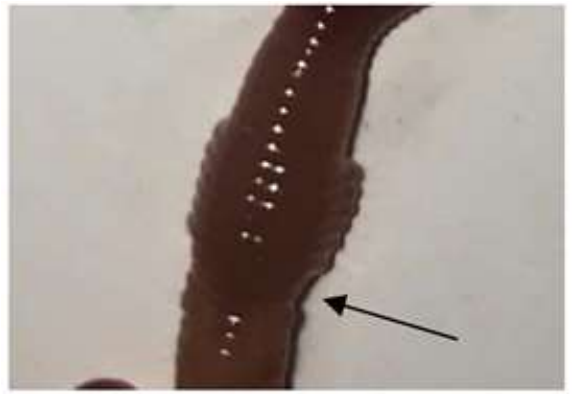

Gambar 5. Identifikasi cacing tanah yang ditemukan di lahan desa sukabanjar, Letak klitelium berada di segmen ke - 24

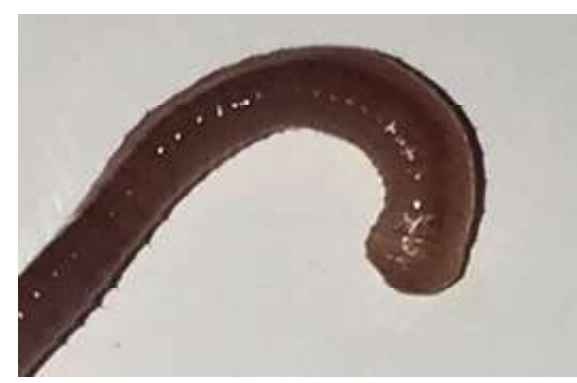

Gambar 6. Alat mulut cacing tanah (prostomium) bertipe Epilobous

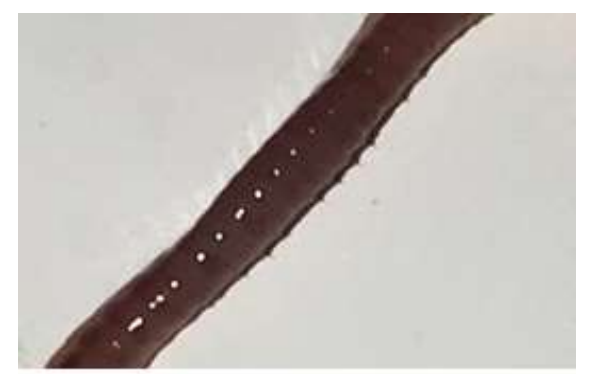

Gambar 7. Bulu halus Cacing Tanah (setae) berpola

tersusun di cincin yang berputar di kanan segmen. cacing berwarna coklat dengan segmen terlihat jelas berwarna hitam kecoklatan, berdasarkan buku panduan Hanafiah dkk, (2005).

\section{Pembahasan}

\section{Populasi dan biomassa cacing tanah}

Berdasarkan hasil penelitian perlakuan pupuk organik menunjukkan berpengaruh nyata terhadap populasi dan biomassa cacing tanah pada pengamatan 45 HST di kedalaman $0-15 \mathrm{~cm}$ dan $15-30 \mathrm{~cm}$ dan
90 HST di kedalaman $0-15 \mathrm{~cm}$. Pupuk kandang ayam menghasilkan populasi dan biomassa cacing tanah lebih tinggi dibandingkan pemberian pupuk jerami dan tanpa pupuk organik. Hal tersebut diduga karena pupuk kandang ayam merupakan sumber hara yang penting karena mempunyai kandungan $\mathrm{C}$ yang lebih tinggi. Pupuk kandang ayam merupakan sumber yang baik bagi unsur hara makro dan mikro yang mampu meningkatkan aktivitas mikroba, sehingga cepat terdekomposisi dan melepaskan hara. Selain itu pupuk kandang ayam dapat memperbaiki struktur fisik dan biologi tanah dan juga mengandung substrat yang dapat berfungsi meningkatkan pertumbuhan dan perkembangannya cacing tanah. (Risnandar, 2004)

Tingginya populasi dan biomassa cacing tanah pada perlakuan pupuk kandang ayam disebabkan kandang ayam mengandung 18,22\% C-organik, 2,23\% Nitrogen, dan memiliki nisbah $\mathrm{C} / \mathrm{N}$ rasio 8,2 . Pupuk kandang ayam dapat memberikan kontribusi bahan makanan bagi cacing tanah, karena pupuk kandang ayam mengandung unsur hara dan C- organik (Santoso, 2004).

Pemberian pupuk kandang ayam juga mempengaruhi faktor lingkungan bagi kehidupan cacing tanah. Pada pengamatan 45 HST pupuk kandang ayam memberikan nilai kemasaan tanah dengan rata-rata $\mathrm{pH}$ tanah sebesar 6,4 (Gambar 4), sedangkan pada pupuk jerami pengamatan $45 \mathrm{HST}$ rata-rata $\mathrm{pH}$ tanah sebesar 5,9. Menurut Maftu'ah dan Maulia (2009) cacing tanah dapat bertahan hidup pada $\mathrm{pH}$ netral. $\mathrm{pH}$ optimum untuk kelangsungan hidup cacing tanah antara 6-7,2.

Pada pengamatan 90 HST di kedalaman 15 $30 \mathrm{~cm}$ pemberian bahan organik tidak terlihat nyata, 
hal ini diduga sumber makanan cacing tanah sudah habis dan populasi cacing tanah menurun. Terlihat dari ratarata cacing tanah di kedalaman 15 - $30 \mathrm{~cm}$ hanya 35 ekor $\mathrm{m}^{-2}$. Menurut Shafrudin, dkk., (2005) penurunan jumlah cacing diduga karena kegagalan cacing muda dalam mempertahankan kelangsungan hidup karena kurangnya sumber makanan bagi cacing.

Aplikasi pupuk jerami berbeda nyata dengan pupuk kandang ayam diduga karena unsur hara yang terdapat pada pupuk jerami lebih rendah di bandingkan pupuk kandang ayam ialah 9,4\% C-organik, 0,67 Nitrogen dan memiliki nisbah $\mathrm{C} / \mathrm{N}$ rasio 15,7 (Tabel 2). Kandungan bahan organik dari jerami yang belum terekomposisi menurut Karimi (2006), jerami padi diketahui memiliki kandungan selulosa yang tinggi 39,1 $\%$ dan hemiselulosa, kandungan lignin 12,5\%. Lignin termasuk kandungan serat selulosa yang sulit dicerna oleh cacing tanah yang menyebabkan populasi cacing tanah hanya bertambah sedikit sehingga tidak berbeda nyata dengan tanpa pupuk organik.

Aplikasi pupuk hayati tidak berpengaruh nyata terhadap populasi dan biomassa cacing tanah pada pengamatan 45 HST dan 90 HST di kedalaman 0-15 $\mathrm{cm}$ dan $15-30 \mathrm{~cm}$. Hal ini diduga perkembangbiakan dan aktivitas mikroorganisme tidak berlangsung secara maksimal yang disebabkan oleh kandungan bahan organik yang rendah. Pada penelitian ini kandungan bahan organik pada pupuk kandang ayam ialah Corganik 18,22\% dan $\mathrm{C} / \mathrm{N}$ rasio 8,17, sedangkan pupuk jerami ialah C-organik 9,4\% dan $\mathrm{C} / \mathrm{N}$ rasio 15,66. Maka dari itu pupuk hayati yang mengandung berbagai macam mikroorganisme tidak berperan secara maksimal sehingga tidak mempengaruhi populasi dan biomassa cacing tanah. Kemungkinan lain juga diduga saat musim tanam sering terjadi hujan, di areal penelitian terjadinya kelebihan air yang menyebabkan aplikasi pupuk hayati terlarut pada aliran air dengan aliran air yang lambat, sehingga pupuk hayati tersebut tidak dapat berperan secara optimal oleh tanah dan tanaman serta cacing tanah.

\section{KESIMPULAN}

Berdasarkan hasil penelitian yang telah dilakukan dapat disimpulkan sebagai berikut: Pemberian pupuk kandang ayam memberikan pengaruh yang lebih baik dibandingkan dengan pupuk jerami maupun tanpa pupuk organik terhadap populasi dan biomassa cacing tanah pada pengamatan 45 HST di kedalaman 0-15 cm dan 15-30 cm dan pada pengamatan $90 \mathrm{HST}$ di kedalaman 0-15 cm, Aplikasi pupuk hayati (Bio Max Grow) tidak berpengaruh nyata terhadap populasi dan biomassa cacing tanah di kedalaman 0-15 cm dan 15-30 cm pada pengamatan 45 HST dan 90 HST dan Tidak terjadi interaksi pemberian pupuk organik dan aplikasi pupuk hayati (Bio Max Grow) terhadap populasi dan biomassa cacing tanah di kedalaman 0-15 cm dan $15-30 \mathrm{~cm}$ pada pengamatan 45 HST dan 90 HST.

\section{DAFTAR PUSTAKA}

Agromedia, Redaksi.2007. Panduan Lengkap Budidaya Tomat. Agromedia, Jakarta.

BPS dan Dirjen Horti. 2016. Produksi Tomat di Indonesia, 2013-2015. https:// www.bps.go.id/site/resultTab. Diakses 25 Desember 2018. 
Dalimartha, S dan A. Felix. 2011. Khasiat Buah dan Sayur. Cetakan ke 2. Penebar Swadaya, Jakarta.

Hanafiah, K.A., A. Napoleon dan N. Ghoffar. 2005. Biologi Tanah, Ekologi dan Makrobiologi Tanah. PT. Raja Grafindo Persada. Jakarta. $143 \mathrm{hlm}$.

Karimi, K. 2006. Conversion Of Rice Straw To Sugars By Dilute Acid Hydrolisis. Biomass dan Bioenergy. 30: 247-253.

Maftu'ah, E, dan Maulia, A. S. 2009. Komunitas Cacing Tanah Pada Beberapa Penggunaan Lahan Gambut di Kalimantan Tengah. Berita Biologi 9 (4)Mahdi. S.S, G. I. Hassan, S. A. Samoon, H.A. Rather, Showkat A. Dar dan B. Zahra. 2010. Bio-Fertilizer in organik agriculture. Journal of Phytology. 2(10) : 42-54.

Marzuki, Sufardi, dan Manfarizah.2011. Sifat Fisika dan Hasil Kedelai (Glycine max L) pada Tanah Terkompaksi Akibat Cacing Tanah dan Bahan Organik. Jurnal Manajemen Sumberdaya Lahan. 1(1) : 23-31.

Opena, R.T, and H.A.M. Van der Vossen. 1994. Lycopersicon esculentum Miller. P:199-201. In: J. S. Siemonsma and K. Pileuk (Eds). Plant Resources of South-East Asia. Prosea Foundation, Bogor
Pujisiswanto, H dan D. Pangaribuan. 2008. Pengaruh Dosis Kompos Pupuk Kandang Sapi Terhadap Pertumbuhan dan Produksi Buah Tomat. Prosiding Seminar Nasional Sains dan Teknologi-II 2008 Universitas Lampung, 1718 November 2008 ISBN : 978-979-116574-7 VII-11.

Prayoga, E. S. 2016. Respons Tanaman Bawang Merah (Allium ascalonicum L.) Akibat Aplikasi Pupuk Hayati Dan Pupuk Majemuk NPK Dengan Berbagai Dosis. Skripsi. Universitas Lampung. Lampung. Hlm. 5.

Risnandar, C. 2004. Jenis dan Karakteristik Pupuk Kandang. Bandung: Nuansa Cendekia .

Rubatzky, V.E., dan Ma Yamaguchi, 1998, Sayuran Dunia : Prinsip, Produksi dan Gizi Jilid II, ITB, Bandung

Santoso, B., F. Haryanti dan S.A. Kadarsih. 2004. Pengaruh pemberian pupuk kandang ayam terhadap pertumbuhan dan produksi serat tiga klon rami di lahan aluvial Malang. Jurnal Pupuk. 5(2):14-18.

Shafrudin D, W Efiyanti dan Widanarni. 2005. Pemanfaatan Ulang Limbah Organik dari Substrak Tubifex sp. di Alam. Jurnal Akuakulture Indonesia, 4(2): 97-102. 